\title{
СЕМАНТИКА ПРЕДИКАТІВ МІСЦЕПЕРЕБУВАННЯ В РЕЧЕННЯХ СУЧАСНОЇ УКРАЇ̈СЬКОЇ МОВИ
}

\begin{abstract}
Аналіз семантики предикатів місцеперебування є одним з актуальних завдань дослідження логіко-граматичних типів речення в аспекті взаємодії лексичної та синтаксичної семантики. Мета статті - з'ясувати особливості лексичної семантики предикатів місцеперебування, що несуть комунікативне навантаження в екзистенційних реченнях. Ці предикати представлені дієслівними лексемами різного значення: кольору, звучання, розміщення в просторі тощо. До спільних категоріальних ознак належать непроцесуальність і статичність. Уживання таких дієслів зумовлює семантичні видозміни буттєвих речень. Структура семантики дієслів місцеперебування містить компоненти модифікаційного значення, які допомагають створити образну картину буттєвих станів.
\end{abstract}

Ключові слова: предикати місцеперебування, речення буття, референтність, дієслово, лексична семантика, статичність.

Zhovtobruh V. F. Semantic of Locative Predicates in Sentences of Modern Ukrainian Language. The analysis of the semantics of locative predicates is one of the most important tasks of the study of logical-grammatical sentence types in the aspect of the interaction of lexical and syntactic semantics. The purpose of the article is to find out the features of the lexical semantics of the locative predicates that carry the communicative load in the existential sentences of the modern Ukrainian language. Local predicates are the bearers of the idea of being, existence, localization. In the structure of the existential sentence, these predicates are represented by verbal lexemes of different meanings: localization, the position of an object in space, color, sound, various manifestations of characteristic traits, etc.

In propositions of existence, these predicates are combined with an irreferenced name, whose existence is reported by the sentence. The irreferent name of the subject is not mentioned in the previous text and is entered into the fund of knowledge of the addressee of the broadcast with the possibility of further its characterization. The sentence states the presence of the subject, and the local predicates describe the qualitative signs of the subject of being from different positions. Such communicative load is carried by all verbs, which according to the corresponding logical-grammatical conditions transmit the significance of localization. Despite the fact that the local predicates transmit different lexical meanings, they have common categorical attributes: lack of process value and static. The subject of being remains unchanged during a specific time interval within which the event described occurs. The static sign corresponds most to the ontological nature of existence. Categorical semantics imposes an imprint on the meaning of verbal lexeme. The use of such verbs determines the semantic modifications of existential sentences. The structure of the semantics of various verbs contains components of modifying value, which help to create a figurative picture of existential states. The use of the designated verbal lexeme contributes to the enrichment of the semantics of the existential sentence and the expansion of its expressiveness. Prospects for the study of existential sentences are related to the analysis of those elements of the semantics of the sentence, which are determined by the lexical meaning of the verb in the position of the local predicate.

Key words: location predicates, sentence of being, reference, verb, lexical semantics, static.

\section{Вступ}

Дослідження семантичної організації речення передбачає аналіз типового значення його складників, насамперед предиката як структурного та змістового центру висловлення. Проблема семантики предикатів місцеперебування посідає важливе місце в завданні наукового дослідження 
логіко-граматичних типів речення в аспекті системної взаємодії лексичної та синтаксичної семантики. Предикати місцеперебування, уживані в екзистенційних реченнях, несуть відчутне комунікативне навантаження, тому виокремлення та опис їх семантичних різновидів є актуальним для розширення уявлень про зміст та функційні можливості семантики буття в повноцінному відтворенні картини світу. В українському мовознавстві представлені різноаспектні дослідження речень буття та їх предикатів: особливості будови буттєвих речень (Дмитрук, 2000), формально-граматичний опис буттєвих речень (Лонська, 2001), семантико-синтаксична структура речень локалізованої наявності/відсутності (Мєлєкєсцева, 2012), аналіз речень буття 3 дієсловами звукової ознаки (Ситнікова, 2013), функціональні різновиди буттєвих номінативних речень (Сушинська, 1999). Водночас питання лексичного наповнення семантичних складників буттєвих речень залишається актуальним, і на доцільності подібних описів наголошують фахівці з українського синтаксису. Тому для повноти дослідження необхідно поглибити розгляд семантики дієслівних лексем у позиції предикатів із значенням місцеперебування.

Метою статті є з'ясування особливостей лексичної семантики предикатів місцеперебування, що функціонують у буттєвих реченнях сучасної української мови.

\section{Методи та методики дослідження}

У роботі застосовано метод лінгвістичного спостереження (ідентифікація предикатів місцеперебування в реченнях буття), структурно-семантичного аналізу (інтерпретація семантики зазначених предикатів), метод суцільної вибірки (у процесі добору ілюстративного матеріалу), класифікаційний метод (виявлення диференційних ознак у семантиці предикатів місцеперебування та виокремлення класів мовних одиниць).

\section{Результати та дискусії}

Вивчення науково-теоретичних праць та аналіз мовленнєвого матеріалу, дібраного з творів художньої літератури XX-XXI століть, показує, що модель екзистенційного речення активно використовують у творах української літератури: Іось та Лебедщина - долина з лугами і річкою, де був одинокий наш хуторець з трьох будинків (У. Самчук). Укінці провулку була криниия (Є. Гуцало). Попереду стояло кілька закритих саней з домочадиями князя (В. Малик). 3 правого боку, за поясом, стримів пістоль (О. Пахучий). Під ногами лежсав ніздрюватий сніг, на гілках дерев подекуди поблискували крижані бурульки (Ю. Збанацький). На тонкій зморшкуватій шиї висів на шнурку срібний хрест (В. Малик).

У реченнях із семантикою буття зазвичай стверджується або заперечується існування будь-чого в усьому світі, його фрагменті або внутрішньому мікросвіті людини. Носіями ідеї буття, існування є локативні предикати, семантику яких досліджено в низці робіт вітчизняних і зарубіжних мовознавців (Вихованець, 1993; Грипас, 2008; Грущенко, 1997; Загнітко, 2006; 
Кононенко, 2012; Степаненко, 2004). Розглядаючи предикат як центральну синтаксему простого елементарного речення, I. Р. Вихованець зазначає, що «локативні предикати вказують на просторові стани, процеси або ознаки предмета» (Вихованець, 1993: 138). Учені по-різному класифікують цю групу предикатів і визначають ії обсяг. Загальноприйнятим $є$ семантичний поділ локативних предикатів за ознакою фазовості на предикати переміщення та предикати місцеперебування, або місцезнаходження, зокрема А. П. Загнітко виокремлює в самостійний клас “предикати місцезнаходження, або статальної локалізаціі” (Загнітко, 2006).

Можна погодитись із думкою дослідників, які пов'язують уживання дієслівних лексем у позиції предиката місцеперебування зі специфікою феномену буття як логіко-граматичного змісту речення. Структуру ситуації буття формують такі елементи, як предмет буття, місце його локалізації та відношення між предметом і місцем локалізації: Упередку воза, запряженого парою мишастих коників, сидів дідок у шапиі-вушаниі (В. Шкляр). Далі, за містом, росли й вищі дерева - буки, приміром, два височенних дуби. (Любко Дереш). Нa столі у маленькій вазочщі стояла дубова гілочка з прив'ялим листям і тугими вузликами зелених жолудів (Ю. Мушкетик).

Кваліфікація семантики таких речень як буттєвої підтверджується, поперше, можливістю вживання в них дієслів, що передають значення буття як одиниці словника (бути, знаходитись, розташовуватись). Пор.: На тому боці, ген під обрієм, примостилося село (Є. Гуцало) На тому боці, ген під обрієм, було село. На тому боці, ген під обрієм, знаходилось село. Можливість взаємозаміни дієслівних лексем формує варіанти лексичного наповнення буттєвих речень. По-друге, предмет буття в таких реченнях уживається нереферентно, тобто без опертя на попередній контекст, і входить у повідомлюване, що $€$ типовим для буттєвих речень, зміст яких полягає у ствердженні існування конкретного предмета в тому чи тому фрагменті матеріального світу: Гарно там було влітку, ох, як гарно! Всюди понад берегами, тобто навколо всього села, росли зарості калини (В. Малик). Референтність розглядаємо як потребу мовця замінити вербальним знаком конкретний предмет, водночас нереферентне ім'я предмета вперше згадується в тексті й уводиться у фонд знань адресата мовлення з можливістю подальшої його характеризації.

Речення буття української мови привертають до себе увагу тим, що вони мають широкі можливості щодо лексичного наповнення семантичних складників, передусім предиката. Коло дієслівних лексем різноманітного значення, здатних функціонувати в реченнях буття, вперше було окреслене у відомій праці Н. Д. Арутюнової та Є. М. Ширяєва. Як зазначають дослідники, «буттєва модель речення набуває значного потенціалу для розширення своєї семантики» (Арутюнова \& Ширяев, 1983: 26).

У функції показника буття часто вживають дієслова небуттєвої семантики, тобто дієслова, які не передають значення буття як одиниці словника. Досліджуючи речення з дієсловами звукової ознаки, В. К. Ситнікова слушно зазначає, що «в буттєвих речення з дієсловами звучання основне семантичне 
навантаження припадає саме на дієслово, що позначає характерний звук» (Ситнікова, 2013: 164). Проаналізований мовний матеріал свідчить про значну поширеність подібних предикатів та їхнє лексичне розмаїття: Посеред галявини світилося голубе око озерия (Ю. Винничук). Під молодим дубовим ліском, що кучерявиться на пагорбку, розташувався літній табір (С. Журахович). У розкуйдовженому гіллі шелюгового куша, вирваного з корінням із землі, лежав собака (Е. Гуцало). За чорними штахетами безлистих кущів брязкотіли маршрутні таксі (В. Дрозд). На периферії Мідних Буків (у напрямку левад понад річкою) пустували цілі квартали таких недобудов (Любко Дереш). По боках, звісивши ноги з полудрабків і притримуючи на колінах рушниці, тряслися на вибоїнах два міліціонери в шинелях $і$ картузах з червоними околишами (В. Шкляр). Подібні висловлення мають усі ознаки логіко-граматичного типу буттєвих речень. Як і речення з дієсловами власне буття (бути, знаходитись, існувати), вони повідомляють про наявність об’єкта в певній ділянці предметного світу, а також про його характерну ознаку.

Семантична своєрідність дієслівних лексем, які, поєднуючись із нереферентно вживаним іменем, набувають здатності виконувати роль показника буття, полягає в особливостях структури лексичного значення цих дієслів. Істотною для вживання подібних дієслів у ролі предикатів місцеперебування $€$ ознака непроцесуальності. Предмет буття залишається незмінним протягом конкретного часового відтинку, у межах якого відбувається описувана подія. Дослідники пояснюють це тим, що дієслова в позиції показника буття зазвичай передають статичну ознаку, що найбільшою мірою відповідає онтологічній природі екзистенції. Як зазначає О. Ю. Грипас, «статична природа локативності вербально може бути реалізована дієсловами на зразок бути, перебувати, міститися, розташовуватися» (Грипас, 2008: 292). Цю думку підтримує Л. В. Гмиря, наголошуючи, що подібні предикати «передають статичну дієслівну характеристику предмета, яка відображена в свідомості на основі сприймання зором» (Гмиря, 2008: 16). Тому непроцесуальні дієслова є вживаними в реченнях, що позначають статичні ситуації, якою власне і є ситуація буття, існування. Категоріальна семантика накладає свій відбиток на значення дієслівної лексеми, через що предикат місцеперебування своєрідно репрезентує статичну ознаку як динамічну, цілеспрямовану дію предмета буття.

Аналіз мовленнєвого матеріалу показує, що діапазон дієслівних лексем у буттєвому реченні надзвичайно широкий, що збагачує й урізноманітнює типову синтаксичну семантику. На інваріантне значення буття може нашаровуватись модифікаційна сема положення в просторі: ІІЇхата стояла глибоко в лісі, серед боліт (В. Шкляр). Він довго дивився на стрімкий протилежний берег, де височіли могутні вали і потемнілі від часу та негоди дерев 'яні заборола великого міста (В. Малик). У подібних реченнях зафіксовано дієслівні лексеми стояти, височіти, бовваніти, стирчати, стриміти, лежати, розкинуmucb, висіти, звисати, які виявляють різну частотність уживання. Найуживанішими з цього ряду є дієслова стояти, височіти, лежати. Частотними $€$ також дієслова кольорового значення, звучання, якісної характеристики 
предмета, певних функціональних станів тощо: На білій шийці иервонів разок коралів (В. Малик). Ото лише зозулині черевички жовтіли та ще тут і там цвіли кущики синіх фіалок (В. Шкляр). Над селом посотались угору сірими верболозами дими з коминів (Є. Гуцало). Посередині блищав вишитий сухозліт-

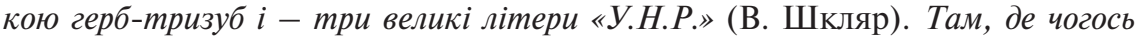
брижилась вода, я побачив золотого кораблика (Б. Антоненко-Давидович). Серед мальовничо-кольористої юрби чорними воронами миготіли черниці різних орденів (О. Іваненко). Комунікативною метою таких речень зазвичай $є$ повідомлення про наявність у певній ділянці конкретних предметів, які мовець виокремлює з навколишнього світу завдяки притаманним їм характерним ознакам. Твердження про місцеперебування цих предметів здійснено через вербалізацію їхніх характеристик.

Іменування буття в дієслові в багатьох випадках невіддільне від якісної характеристики буттєвого стану. Відповідна схема практично пронизує весь масив екзистенційних дієслів і представлена в більшості його угруповань. Це робить дієслівний ряд гнучкою та чутливою організацією, яка в усіх необхідних випадках легко реагує на виниклу потребу не просто іменувати стан буття, але й із різних позицій описати його. Семантика якісного характеру буттєвого стану знаходить своє втілення в компонентах значення, які модифікують екзистенційний зміст речення. Ці компоненти містяться в лексичному значенні дієслова, яке збагачує інваріантну логіко-граматичну семантику. Буття іменується дієсловом з участю модифікаційних асоціативних сем, які створюють образну картину буттєвих станів. Водночас семантичні видозміни буттєвих речень, зумовлені лексичним значенням предиката місцеперебування, можливі в межах запрограмованої попереднім контекстом комунікативної перспективи, у якій є місце лише для нереферентного імені та повідомлення про його існування.

\section{Висновки}

Таким чином, предикати місцеперебування в структурі буттєвого речення представлені дієслівними лексемами різного значення. Це дієслова з семантикою положення предмета в просторі, кольору, звучання, різних проявів характерних ознак тощо. Незважаючи на лексико-семантичну розмаїтість, предикати місцеперебування мають спільні ознаки, до яких належить непроцесуальність у значенні дієслова та статичність. Категоріальна семантика накладає свій відбиток на значення дієслівної лексеми. Уживання таких дієслів зумовлює семантичні видозміни буттєвих речень. Структура семантики різноманітних дієслів, здатних за відповідних умов передавати зміст місцеперебування, містить компоненти модифікаційного значення, які допомагають створити образну картину буттєвих станів. Уживання означених дієслівних лексем сприяє збагаченню семантики буттєвого речення та розширенню його виражальних можливостей. Перспективи дослідження буттєвих речень пов'язані з аналізом тих елементів семантики речення, що зумовлені лексичним значенням дієслова в позиції предиката місцеперебування. 


\section{ЛІТЕРАТУРА}

1. Арутюнова Н. Д., Ширяев Е. Н. Русское предложение. Бытийный тип: структура и значение. Москва : Русский язык, 1983. 198 с. 2. Вихованець І. Р. Граматика української мови. Синтаксис. Київ : Либідь, 1993. 383 с. 3. Гмиря Л. В. Семантикосинтаксична структура речень $з$ двовалентними дієслівними предикатами: автореф. дис. на здобуття наук. ступеня канд. філолог. наук : 10.02.01. Київ : НПУ, 2008. 25 с. 4. Грипас О. Ю. Формально-синтаксична структура речення з пропозиційним предикатом набуття/втрати локативності. Науковий часопис Національного педагогічного університету імені М. П. Драгоманова. Серія 10. Проблеми граматики і лексикології української мови : зб. наук. пр. Київ : НПУ, 2008. Вип. 3. Кн. 2. С. 292-300. 5. Грущенко Л., Іваницька Н. Семантика статичного локативного предиката двоскладного речення дієслівної будови в українській. Актуальні проблеми синтаксису: Матеріали Всеукраїнської наукової конференції, присвяченої 85-річчю проф. I. Слинька. Чернівці: Рута, 1997. С. 56-57. 6. Загнітко А. П. Теорія сучасного синтаксису. Донецьк : ДонНУ, 2006. 368 с. 7. Дмитрук В. І. Особливості структури буттєвих речень в українській мові. Наукові записки Кіровоградського держ. пед. ун-ту. - Сер. Філологічні науки. - Кіровоград : РВЦ КДПУ ім. В. Винниченка, 2000. Вип. 30. С. 181-187. 8. Кононенко В. І. Слов'янські мови в типологічному вимірі. Українська та польська мови : контрастивне дослідження. Warszawa : WUW, 2012. С. 15-25. 9. Лонська Л. I. Структурно-семантичні особливості буттєвих речень в українській мові : автореф. дис. на здобуття наук. ступеня канд. філол. наук: 10.02.01. Київ, 2001. 19 с. 10. Мєлєкєсцева Н. В. Семантикосинтаксична структура речень локалізованої наявності/відсутності. Науковий часопис Національного педагогічного університету імені М.П.Драгоманова. Серія 10 : Проблеми граматики і лексикології української мови. 2012. Вип. 9. С. 146-153. 11. Ситнікова В. К. Аналіз імені предмета буття на прикладі речень з дієсловами звукової ознаки. Science and Education a New Dimension: Philology, I(3), Issue: 13, 2013. C. 163-166. 12. Степаненко М. І. Просторові поширювачі у структурі простого речення. Полтава : АCMI, 2004. 464 с. 13. Сушинська I. М. Функціональні різновиди буттєвих номінативних речень Лінгв. студії: зб. наук. пр. Донецьк : ДонДУ, 1999. Вип.5. С. 173 -178.

\section{REFERENCES}

1. Arutyunova, N. D. \& Shiryayev, E. N. (1983) Russkoye predlozheniye. Bytiynyy tip: struktura i znacheniye [Russian sentence. Existence type: structure and meaning]. Moskva : Russkyi yazyk [in Russia]. 2. Vykhovanets, I. R. (1993) Hramatyka ukrainskoi movy. Syntaksys [Grammar of the Ukrainian language. Syntax]. Kyiv : Lybid [in Ukrainian]. 3. Hmyria, L. V. (2008) Semantyko-syntaksychna struktura rechen $\mathrm{Z}$ dvovalentnymy diieslivnymy predykatamy [Semantic-syntactic structure of sentences with divalent verb predicates] $E x$ tended abstract of candidate's thesis. Kyiv : NPU, [in Ukrainian]. 4. Hrypas, O. Iu. (2008) Formalno-syntaksychna struktura rechennia z propozytsiinym predykatom nabuttia/vtraty lokatyvnosti [Formally-syntactic structure of sentence with propositional predicate of acquisition / loss of locality]. Naukovyi chasopys Natsionalnoho pedahohichnoho universytetu imeni M. P. Drahomanova. - Scientific journal of M. P. Drahomanov National Pedagogical University: collection of scientific works (Series 10. Problems of grammar and lexicon of the Ukrainian language), (Vols 3, book 2), (pp. 292-300). Kyiv : NPU, [in Ukrainian]. 5. Hrushchenko, L. \& Ivanytska, N. (1997) Semantyka statychnoho lokatyvnoho predykata dvoskladnoho rechennia diieslivnoi budovy v ukrainskii movi [Semantics of the static locative predicate of a two-tongue sentence of the verb structure in the Ukrainian language] Aktualni problemy syntaksysu - Actual syntax problems: Proceedings of the All-Ukrainian Scientific Conference devoted to the 85th anniversary of prof. I. Slynka. (pp. 56-57). Chernivtsi : Ruta [in Ukrainian]. 6. Zahnitko, A. P. (2006). Teoriia suchasnoho syntaksysu [The theory of modern syntax]. - Donetsk : DonNU 
[in Ukrainian]. 7. Dmytruk, V. I. (2000) Osoblyvosti struktury buttievykh rechen v ukrainskii movi [Features of the structure of existential sentences in the Ukrainian language] Naukovi zapysky Kirovohradskoho derzh. ped. un-tu. - Ser. Filolohichni nauky. - Scientific notes of the Kirovohrad State Pedagogical University. - Series Philology. (Vols. 30), (pp. 181-187). Kirovohrad : RVTs KDPU im. V. Vynnychenka [in Ukrainian]. 8. Kononenko, V. I. (2012). Slovianski movy v typolohichnomu vymiri [Slavic languages in a typological dimension] Ukrainska ta polska movy : kontrastyvne doslidzhennia - Ukrainian and Polish languages: contrastive research (pp. 15-25). Warszawa : WUW [in Poland]. 9. Lonska, L. I. (2001). Strukturno-semantychni osoblyvosti buttievykh rechen v ukrainskii movi [Structural-semantic features of existential sentences in the Ukrainian language]. Extended abstract of candidate's thesis. Kyiv: NPU imeni M. P. Drahomanova [in Ukrainian]. 10. Mieliekiestseva, N. V. (2012) Semantyko-syntaksychna struktura rechen lokalizovanoi naiavnosti/vidsutnosti [Semantic-syntactic structure of sentences of localized presence / absence]. Naukovyi chasopys Natsionalnoho pedahohichnoho universytetu imeni M. P. Drahomanova -Scientific journal of M. P. Drahomanov National Pedagogical University (Series 10. Problems of grammar and lexicon of the Ukrainian language), (Vols 9), (pp. 146-153). Kyiv : NPU, [in Ukrainian]. 11. Sytnikova, V. K. (2013) Analiz imeni predmeta buttia na prykladi rechen z diieslovamy zvukovoi oznaky [Analysis of the name of the subject of being on the example of sentences with the verbs of the sound sign]. Science and Education a New Dimension: Philology, I(3), Issue: 13, 163-166. [in Ukrainian]. 12. Stepanenko, M. I. (2004) Prostorovi poshyriuvachi u strukturi prostoho rechennia [Spatial distributors in the structure of a simple sentence]. Poltava : ASMI [in Ukrainian]. 13. Sushynska, I. M. (1999) Funktsionalni riznovydy buttievykh nominatyvnykh rechen [Functional varieties of existential nominative sentences]. Linhv. studii: zb. nauk. pr. - Linguistic studios: a collection of scientific works. (Vols 5), (pp. 173-178). Donetsk : DonDU [in Ukrainian].

Жовтобрюх Валентина Федорівна - кандидат філологічних наук, доцент кафедри українознавства і мовної підготовки іноземних громадян, Харківський національний економічний університет імені Семена Кузнеця; просп. Науки, 9-А, м. Харків, 61166, Україна.

Tel.: +38-063-425-07-17

E-mail: zhovtobruhvalentina@gmail.com

https://orcid.org/0000-0003-0953-3017

Zhovtobruh Valentina Fedorivna - PhD in Philology, Associate Professor, Department of Ukrainian Studies and Language Preparation of Foreign Citizens, Kharkiv National University of Economics named after Semen Kuznets; Nauky Av., 9-A, Kharkiv, 61166, Ukraine. 